\title{
leva Libiete
}

\section{DEVELOPMENT OF PSYCHIATRY IN LATVIA BETWEEN 1918 AND 1940}

\author{
Summary of the Doctoral Thesis \\ for obtaining the degree of a Doctor of Medicine \\ Speciality - History of Medicine
}

Riga, 2014 


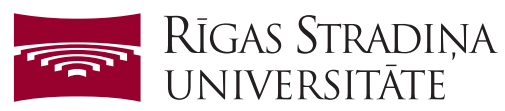

Ieva Lībiete

\section{DEVELOPMENT OF PSYCHIATRY IN LATVIA BETWEEN 1918 AND 1940}

Summary of the Doctoral Thesis

for obtaining the degree of a Doctor of Medicine

Speciality - History of Medicine

Rīga, 2014 
The study was conducted at: Institute of History of Medicine, Rīga Stradinš̌ University

Scientific supervisors:

Dr. med. Professor Juris Salaks, Institute of History of Medicine, Rīga Stradinš̌ University, Latvia

Dr. med. Associate Professor Biruta Kupča, Faculty of Medicine, Department of Psychiatry and Narcology, Rīga Stradiņš University, Latvia

Scientific consultant:

Dr. hist. Rita Grāvere, Pauls Stradins Museum of History of Medicine, Latvia

Official reviewers:

Dr. med. Professor Elmārs Rancāns, Faculty of Medicine, Department of Psychiatry and Narcology, Rīga Stradinš University, Latvia Dr. med. Professor Arnis Vīksna, Faculty of Medicine, Department of Pedagogy, Ethics and History of Medicine, University of Latvia Ph. D. Professor Emeritus Vieda Skultāne, School of Sociology, Politics and International Studies, University of Bristol, United Kingdom

The Doctoral Thesis will be defended on $5^{\text {th }}$ of June 2014, at 16.00 during Rīga Stradiņš University Medical Degree Committee open meeting in Pauls Stradins Museum of History of Medicine, 1 Antonijas Street, Riga

The Doctoral Thesis is available at RSU library and RSU website: www.rsu.lv

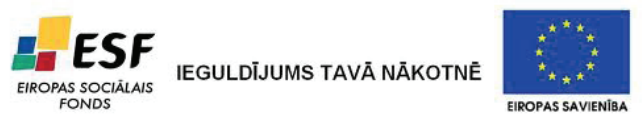

The thesis was co-funded by the ESF project "Support for Doctoral Students in Mastering the Study Programme and Acquisition of a Scientific Degree in Riga Stradinš̌ University", agreement No. 2011/0056/1PD/1.1.2.1.2/11/IPIA/VIAA/006

Secretary of the Degree Committee:

Dr. med. Professor Ināra Logina 


\section{CONTENTS}

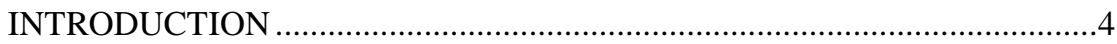

1. THE ROLE OF PSYCHIATRY IN THE HEALTH CARE SYSTEM ..........7

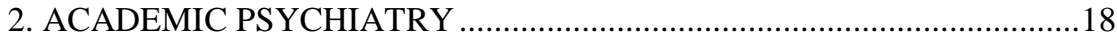

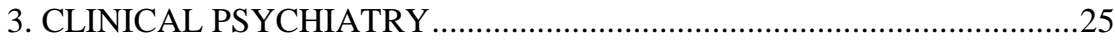

4. THE ROLE OF PSYCHIATRY IN SOCIAL PROCESSES .........................32

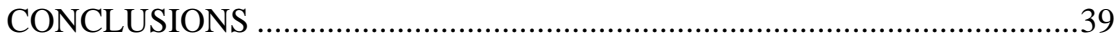

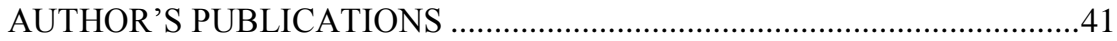

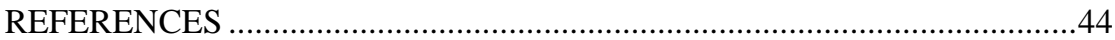




\section{INTRODUCTION}

One of the most rapidly growing and, in many cases, contradictorily interpreted and attention-attracting fields in the history of medicine in the past several decades has been the history of psychiatry. This is a multidisciplinary field of study, and in the literature, one finds the desires of some authors to politicize various aspects of the history of psychiatry. This has led to a situation in which the history of psychiatry has developed as an important academic discipline.

The history of psychiatry has been studied in Latvia, but there has been no major study which evaluates psychiatry between the two world wars from various unprecedented aspects. This is true even though that period - the last few decades before the flourishing of psychopharmacology - was very dynamic and important in Latvian psychiatry. It was a period during which a national school of psychiatry was established in Latvia. Institutionalised psychiatry expanded during this period and so-called somatic therapy methods were introduced in clinical practice. This changed psychiatry in a fundamental manner in Latvia, as in the rest of the world, concluding the process of medicalization that began in the $19^{\text {th }}$ century. For that reason, these essential decades in Latvian psychiatry deserve a more detailed discussion and evaluation.

The chronological boundaries of the study relate to the period of independence of the Republic of Latvia between 1918 and 1940. In order to depict the essence of certain aspects of the history of psychiatry more completely, however, the author will also discuss some of the developments of psychiatry which occurred during World War II. During the war, scientific 
development of psychiatry was insignificant, if any, but the period that is reviewed here concludes completely only after the end of the war. During the period of Latvian independence, Professor Hermanis Buduls established a school of psychiatry which lasted until 1944, when most of Latvia's academic faculty members and practicing physicians were forced to emigrate.

The aim of this research is to conduct a scholarly study of the development of psychiatry in Latvia between 1918 and 1940 and to describe it as an essential component of the country's health care system and as a scientific and clinical practice, also assessing the role of psychiatry in social processes. A key component in this goal is the review of psychiatric events and processes in Latvia in the context of Western psychiatry as such.

The objectives of the paper are to identify, correlate and examine available sources and literature, using them to characterise:

1) Psychiatry as a component of the health care sector;

2) Psychiatry as a scholarly discipline;

3) Psychiatry as a clinical practice;

4) The role of psychiatry in social processes.

Sources and literature used for this study include unpublished sources from the Latvian State Historical Archives and the Pauls Stradins Museum of the History of Medicine, as well as published sources such as minutes from parliamentary debate, statistical compendia, the press and publications published during the period that is examined here (academic, scholarly and popular works) - sources that has hardly ever been used for research studies. The literature includes historiography.

The structure of the dissertation is based on the aim and objectives of the research. There are four chapters: 1) The role of psychiatry in the health 
care system; 2) Academic psychiatry; 3) Clinical psychiatry; 4) The role of psychiatry in social processes. The chronological principle has been observed in the study to a certain extent, primarily focusing attention on the individual development of each of the relevant issues.

The practical importance of the dissertation relates to the fact that there has been no universal study of psychiatry in Latvia during the inter-war period. The research is an investment in the study of the history of psychiatry during the first half of the $20^{\text {th }}$ century, because it discusses aspects of the history of psychiatry in Latvia that have never been considered before. The second practical meaning of the dissertation is that thanks to this study, there has been created broader and unbiased understanding in society about the history of psychiatry. This was achieved in an exhibition devoted to the history of Latvian psychiatry at the Pauls Stradins Museum of the History of Medicine and the Strenči Psycho-neurological Hospital Museum, "The Story of the Straitjacket: Psychiatry before Psychopharmacology." The author has used traditional research methods, including the historically genetic, historically comparative and historically systemic methods. 


\section{THE ROLE OF PSYCHIATRY IN THE HEALTH CARE SYSTEM}

The first steps toward a national and organised network of psychiatric care in the Russian Empire were taken by Empress Catherine the Great, who proclaimed a special law in 1775 which spoke to the establishment of social care institutions in the various provinces of the empire. Among their duties was to create special treatment facilities for insane people. In 1824, the Vidzeme (Livonia) Board for Social Care established the Alexander Heights Institution, and one department therein was dedicated to the treatment of people with mental disorders. A public care hospital was established in Kurzeme (Courland) in 1824, and it also had treatment facilities for such people. The period of a medical approach toward psychiatry began, to a certain extent, with the establishment of the Sarkankalns Hospital in Rīga (1862). Unlike the aforementioned institutions, this one was meant specifically for the treatment of psychiatric patients.

Several other psychiatric care institutions were established after the aforementioned ones - Tabors (1887) and the Ģintermuiža Hospital (1901) in Jelgava (the two of them being merged in 1921), as well as a psychiatric hospital at Strenči (1907). Psychiatric treatment was also offered by psychiatric departments at general hospitals in Kuldīga (1890-1908 or 1909) and Liepāja (1904). Private clinics run by the Šenfelds doctors offered care for a small number of patients who could pay for the services in the Pārdaugava region of Rīga (from 1897) and by the Sokolovskis private clinic in Rīga (1898-1918?). Despite the fact that many psychiatric hospitals were established in the Russian Empire, including Latvia, in the late $19^{\text {th }}$ and early $20^{\text {th }}$ century, home and 
community care were convincingly dominant when it came to the treatment of mental diseases. During the early $20^{\text {th }}$ century, when Tsar Nicholas II was on the throne, the number of inpatient psychiatric hospitals was negligible and unnoticeable in comparison to the large population of the empire.

The situation with the organisation of psychiatric care in Latvia changed after World War I, when the independent Republic of Latvia was established. The first institution to deal with health care issues in Latvia was the Kurzeme Medical Board that was established in Liepāja in March 1919 by the Interior Ministry. In August of the same year, it was turned into the Health Department of the ministry, and it was the highest-ranking institution to oversee treatment and sanitary issues. Later, in 1925, the department was turned over to the Labour Ministry, and it became known as the People's Welfare Ministry. Its Health Department was the main health care governance institution until World War II, and all of the country's psychiatric hospitals were under its domain. The Health Department also oversaw institutions which treated people suffering from leprosy, as well as institutions which dealt with health resorts.

During the latter half of 1919 and at the beginning of 1920, the Health Department took control of hospitals and treatment institutions which had offered psychiatric care during the pre-war years and had lost financing afterward - the hospital built by the Vidzeme knighthood in Strenči, the Vidzeme Governorate Social Care Alexander Heights Hospital in Rīga, the Kurzeme Governorate Social Care Hospital "Stallıplacis" in Jelgava, the Ģintermuiža Psychiatric Hospital that was built by the Kurzeme knighthood, and the nearby Tabor institution which had been established by the synod of pastors in Kurzeme. "Stallplacis" was soon shut down for economic reasons, and psychiatric patients were transferred to the Tabor institution or the 
Ģintermuiža Hospital. The Sarkankalns Hospital in Rīga, which was owned by the city before the war, was taken over by the Riga City Health Department. Alongside these three Health Department hospitals and the Sarkankalns Hospital in Rīga, there was also a psychiatric department at the Liepāja City Hospital, as well as the Šenfelds private clinic in Rīga. The latter two, however, had few beds for patients.

After the takeover of the hospitals, as of January 1, 1920, the Strenči, Ģintermuiža and Alexander Heights hospitals, the Tabor institution and the Sarkankalns Hospital treated approximately 1,050 patients. During the first years after the war, the number patient beds at psychiatric hospitals substantially exceeded the number of inpatients. This was because poor conditions during the war, famine and epidemics led to the death of large numbers of psychiatric inpatients.

During the first few years after the war, however, it became clear that the number of people with mental diseases who required hospitalisation was increasing rapidly. During 1923, the four large psychiatric hospitals and the psychiatric ward at the Liepāja Hospital had 1,225 beds for mentally ill patients. They had too many inpatients, and people who had freshly been diagnosed with mental disorders often had to be turned away. For that reason, the Health Department declared in 1923, when it entered its fifth year of operations and found increasing tensions in the psychiatric care sector, that the priority would be to expand existing psychiatric hospitals and to build a new psychiatric treatment facility in Daugavpils. The Daugavpils Psychiatric Hospital was opened with 100 beds in 1924, but by the end of the 1930s, it had expanded to 800 beds. Between 1923 and 1938, the number of beds at the Strenči Hospital increased from 250 to 365 , at Ģintermuiža it rose from 350 to 
620, and at the Sarkankalns Hospital it grew from 400 to 788 . The increase at the Alexander Heights Hospital was the lowest - from 200 to 240 beds. In the summer of 1934, a psychiatric ward for chronic patients was opened at the Rìga No. 2 Hospital. Two new private clinics were opened, too. The "Atgāzene" clinic of A. Šēnfelds was opened in 1933 with 35 beds, and Dr Mellers opened a private clinic with ten beds in 1936.

As the number of hospitals increased, the total number of psychiatric beds in Latvia increased year by year - 2,364 in 1929, 2,710 in 1935, and 3,048 beds for Latvia's population of nearly two million people in 1938. The number of inpatient patients in the late 1930s was more than 2.5 times higher than was the case during the first years after the war. In comparison to several other European countries such as the Netherlands and Switzerland, the number of psychiatric beds in Latvia was as much as two times lower. In Latvia's neighbouring country of Lithuania, as well as in Poland, however, the number of beds was proportionally even smaller than in Latvia. In 1937, Lithuania had only 500 psychiatric beds for more than 2.5 million residents.

The demand for inpatient psychiatric treatment continued to increase during the inter-war period. It was not due to increased population numbers in Latvia or an increase in the number of people who were sick. Instead the issue was changes in public attitudes toward psychiatric care. After industrialisation and urbanisation, attitudes toward mental diseases and toward the institution of psychiatry as such altered. The result was a change from traditional home care to treatment at a medical institution.

In addition to overall changes in attitudes toward psychiatry, another reason for increased demand for inpatient psychiatric treatment related to economic considerations. Compared to the pre-war years, it was easier for 
patients to receive psychiatric treatment in hospitals and to spend more time there, because treatment costs, which during the pre-war period largely rested on the shoulders of the patients and their relatives, were mostly covered by the national or local government budget or from health insurance institutions.

The third very important reason for the excessive number of psychiatric inpatients was that social care in the country was not in good order. There was a lack of shelters for poor people with mental diseases, and so it was difficult to discharge patients from hospital who no longer needed medical treatment. The turnover of psychiatric inpatients was very slow. What is more, the number of admitted patients each year was higher than the number of released or deceased patients. For that reason, the aforementioned expansion and improvement of the hospitals could not address the main problem - the fact that there was no place where calm chronic patients could be housed. At the end of 1925, for instance, approximately $3 \%$ more patients were being treated at psychiatric hospitals than there were beds. People who did not have beds in hospital were known as "bezgultnieki" or the "bedless". Their maximum number was seen in late 1935, when a bit more than $10 \%$ of patients were "bedless".

The excessive number of patients and the ongoing lack of psychiatric beds made it difficult to admit patients to hospitals, even though theoretically the admission process was very simple. When the independent Latvian state was established, the treatment of psychiatric inpatients continued to be regulated by former Russian civil law and new government regulations which stated that all that was needed to admit a patient to a psychiatric hospital was a "confirmation" from a single doctor. What's more, the doctor did not need to be a psychiatrist. Identity card of a patient was needed, and payment for 90 days in a hospital in advance. If a person was not able to pay the money, there had to be 
certification from the relevant municipality institution to say that it would pay for the treatment of the patient. People who were already admitted to hospitals did not have to be reported to the courts, though patients had to be registered with the local police. Care about the property of the patient was theoretically assigned to orphanage courts, but the ongoing presence of the patient at hospital was entirely in the hands of the relevant physician. A similar system was preserved after amendments that were approved in 1939 to say that patients would be admitted by the institutions director on the basis of the number of free beds at the hospital.

Despite the easy admission system for patients, queues for admissions at psychiatric hospitals were enormous because of the aforementioned excessive number of inpatients. For that reason, admission of new and acutely ill patients was often encumbered. Usually admission was not refused only for those patients who "endangered other citizens," while others had to wait in a long queue before being admitted for inpatient treatment.

If a patient's relatives refused to care for the mentally ill individual, then that was first and foremost a problem for the relevant municipality. This procedure was officially confirmed by the Health Department in 1933, specifying that mentally ill people who could not be admitted to hospital because of a lack of beds had to receive care from their relatives. If the relatives were poor and could not care for the patient, then the burden fell on the shoulders of the relevant local government. It, in turn, had to find a care facility for the patient, as well as a place where the patient could live until such time as the facility was found. Most local governments had no facilities even for the short-term housing of psychiatric patients, but they were not allowed to send patients to psychiatric hospitals without previous contacts with the relevant 
hospital (or, beginning in 1929, with the People's Welfare Ministry). This led to dissatisfaction among local governments.

There were also conflicts between local governments and the national government throughout the inter-war period with respect to financing for the treatment of patients who could not pay for their own treatment. Government regulations determined the cost of treatment at psychiatric hospitals. Between 1925 and 1939, the cost for Latvian citizens did not change - LVL 1 per day in the third-grade facilities, LVL 1.50 a day for second-grade facilities (rooms with two to three patients), and LVL 2.50 a day for single rooms. Because of the aforementioned lack of inpatient beds, single rooms or rooms with few patients were uncommon. Because such grades did not exist in reality at psychiatric hospitals, a single and fixed treatment cost was approved in 1939 for patients at hospitals for the mentally disabled - LVL 3 per day for Latvian citizens. The cost at the Sarkankalns Hospital was determined by the Rìga City Council, and it was commensurate with the cost of treatment at other hospitals in the country.

The involvement of state and local government institutions in the financing of psychiatric care was based on the Law on Social Care which took effect in 1928. The state and local governments were obliged to take care of poor people, disabled people, orphans, defective children, patients with dangerous contagious diseases, as well as mentally ill people who required treatment at "special institutions." The law spoke about "insane people who have been admitted to special state institutions" and were subject to social care. Local governments were obliged to pay no more than one-third of the actual cost of treating the patient, paying that money to the national government. If a patient was not in one of the categories related to social care, the law said that 
between one-third and all of the money that was needed would be collected from his or her relatives or by selling his or her properties. In the event, most psychiatric patients had the required social care status, so basically the law meant that local governments financed one-third of their treatment costs.

Because treatment for mentally disabled people was difficult to obtain due to the lack of room at hospitals and because the state collected money from parish and district boards for patients who had been treated, local governments grew more and more dissatisfied with the situation. The national government, in turn, claimed that local governments were not ensuring the sufficiently quick discharge of treated and calm patients from hospital. In order to deal with the dissatisfaction of local governments, the law on social care was amended in 1935 to say that from then on, the state, no longer with local government participation, would fully finance the "housing of insane people at special institutions who, in accordance with the terms of this law, are related to rural local governments." This, in turn, led to objections from urban local governments, which also believed that the state should fully pay for the treatment of insane people. The law was amended once again in 1939 to say that local governments must pay no more than one-third of the treatment cost of such patients, the sum being based on the actual treatment cost or on the published cost of treatment. The amendments also reduced the amount of money to be collected from the patient's relatives or properties to one-tenth of the actual cost.

It was clear that the housing of chronic mentally diseased patients at psychiatric hospitals was not only unjustified, but also financially disadvantageous. One of the solutions proposed by the Health Department was to liberate hospitals from calm chronic patients who did not require special 
treatment. In 1936, it was decided to reinstate the pre-war tradition of transferring calm chronic patients to their families for care purposes. Such families received between LVL 16 and 30 a month as compensation for the care. Although this initiative was not much considered in cities, it gradually gained increasing response in the countryside. In 1939, 222 patients were released from state psychiatric hospitals for home care, and 145 of them came from the Daugavpils Psychiatric Hospital, which had 800 beds in all. Patients could be given home care in one of two ways - either by their own relatives or by strangers. It was easier to send patients to their families, but it was seen as more promising to house them with "foster families." In most cases, this involved farms at which patients could do simple but useful work insofar as they were able to do so. The hope was that this placement and employment of patients at farms would eventually lead to the establishment of a psychiatric colony of the type of one in Belgium, Geel, which had very good practices, indeed. This, the government felt, could substantially reduce the cost of housing patients.

Plans to establish such a colony in Latvia were made during the late 1920s, when discussions began about the establishment of a psychiatric colony at the Pope Estate in the Ventspils District. The government saw more in the way of opportunities to save money, because it was anticipated that such colonies would certainly involve lower costs than was the case with keeping patients in a psychiatric hospital, and psychiatrists believed that this would offer major benefits to the patients themselves. In 1929, a detailed budget plan for the 1929/1930 national budget was prepared for a chronically insane hospital and shelter at the Pope Estate. The document shows that the plan was to house 150 chronic patients at the colony, offering them jobs related to 
farming, animal husbandry and various workshops. The patients were to receive a wage for their work, but at the end of the day, the colony at Pope was not established.

The first psychiatric colony in Latvia was only established during World War II in Giimnastikas Street in Rīga. It only survived for a brief period of time - from the beginning of 1941 until June of the same year. The origins for the colony, however, were created at an earlier time, in early 1940, when a special shelter was established in Rīga for mentally ill people at Ģimnastikas Street 1, with some 460 beds planned for the shelter. 265 chronically ill patients were transferred to the shelter from the Sarkankalns Hospital and the Riga No. II Hospital, as were all mentally deficient people who had lived at other shelters. It is known that only 24 mentally ill patients were transported to the Ģimnastikas Street shelter from other shelters, which suggests that the proportion of mentally disabled people at the shelters was rather small.

At the beginning of 1941, when the Soviet occupation was already in place, the shelter in Gimnastikas Street was transformed into a psychiatric colony. The establishment of the first colony in Latvia relates to the psychiatrist Arnolds Laksbergs (1901-1983). In accordance with the colony's goals, qualified professionals were hired to lead workshops. The space of the colony soon became too narrow, and so in May 1941, the People's Commissariat for Health Care decided to attach the former nerve clinic of Dr A. Šenfelds, which was nearby and had been nationalised by the Soviet regime. The psychiatric colony operated until the arrival of Nazi forces in the summer of 1941, when it was shut down.

The most tragic events in the history of psychiatry in Latvia occurred during the Nazi occupation, when the German authorities murdered most 
mentally ill inpatients. This led to the transformation of the Daugavpils Psychiatric Hospital into a field hospital. In April 1942, the Sarkankalns Hospital was shut down and turned over to the SS as another field hospital. The psychiatric ward of the Rìga No. II Hospital was also shut down. The Health Department of the Interior General Directorate of Latvian Self-Governance only had control over three psychiatric hospitals - the Alexander Heights Hospital, the Strenči Hospital, and the Ģintermuiža Hospital.

The German occupation was also fateful for Jewish doctors and psychiatrists. We know that seven Jewish psychiatrists died during the war at the Rìga ghetto, at concentration camps and elsewhere. The destiny of three other Jewish psychiatrists or nerve doctors is unknown.

There were only 28 specialists practicing in Latvia in 1943 (as opposed to the maximum number of 51 psychiatrists and nerve doctors between the wars). Most of the psychiatrists who survived the war chose to emigrate. After the Soviet occupation was restored after the war, there were only 17 psychiatrists or psychiatric neurologists registered in Latvia (1946). Only eight of them had practiced in Latvia before the war, so it would be no exaggeration to say that during the post-war era, the old Latvian school of psychiatry no longer existed. It was replaced by the very different Soviet school of psychiatry. 


\section{ACADEMIC PSYCHIATRY}

The origins of psychiatry as a clinical discipline can, to a certain extent, be dated back to 1862 , when the Sarkankalns Hospital was opened in Rīga specifically for psychiatric patients. Psychiatry turned into a scientific medical sector in Latvia after World War I, when the collapse of the Russian Empire led to the establishment of the independent Republic of Latvia (1918) and the University of Latvia was established (1919) with a Faculty of Medicine. All medical students at the university studied psychiatry, and this created the first generation of Latvian psychiatrists.

We can say that the Department of Psychiatry was originated on June 9, 1920, when Hermanis Buduls (1882-1954) was elected to the Faculty of Medicine as a docent. He was responsible for putting together a new Department of Psychiatry and Nervous Disorders. Buduls was a graduate of the University of Tartu (Yuryev at that time, 1911), where he was taught by the distinguished Russian psychiatrist Vladimir Chizh (1855-1922). He also worked as an assistant at the Clinic for Nervous and Mental Diseases (1910-1914). While working at Tartu, Buduls tracked progress in psychiatry and began to study the etiology and statistics of progressive paralysis. His doctoral dissertation was based on his epidemiological studies, and it was titled "On the Comparative Psychiatry of the Races". He defended it in 1914. Once at the University of Latvia, Buduls created interest at his department in progressive paralysis and the epidemiology and heritability of psychiatric diseases. Buduls was biologically oriented psychiatrist, and he agreed with the theory of neurogenic origins for psychiatric diseases. He did not deny psychogenic causes, but he did consider them to be rather less than important. 
Because Buduls was the only professor of psychiatry (as of 1924) and the only head of the Department of Psychiatry at the University of Latvia during the period between the wars, his professional views had major influence on psychiatrists who graduated from the University of Latvia during that period.

Buduls' primary contribution toward the development of the Latvian school of psychiatry was not the scholarly research work that he did; instead, focus must be on the fact that he could choose the most capable medical students and graduates for work at the department, creating the best possible conditions for their scientific work and its development. Under Buduls' leadership, a laboratory was established at the Sarkankalns Hospital for histological, biological and chemical examinations. The department's library was regularly updated.

In addition to Professor Buduls, the Department of Psychiatry hired two assistants beginning in 1921. Miķelis Kazaks (1884-1968) worked under Buduls' leadership at the Department of Psychiatry from 1922 until 1923, Ansis Karps (1892-1979) did so from 1921 until 1927, Nikolajs Jerums (1904-1991) worked there in 1927 and 1928, Verners Kraulis (1904-1944) did so from 1924 until 1941, Hermanis Saltups (1901-1968) served as an assistant from 1928 until 1934, and Jānis Vilde (1900-1971) followed suit from 1934 until 1939.

In 1921, the Sarkankalns Hospital became the clinical facility for the Department of Psychiatry. It was used to deliver lectures and to study clinical psychiatry. The initial intention to merge the disciplines of psychiatry and neurology under one umbrella failed, because the Sarkankalns Hospital was a specialised psychiatric clinic and did not have sufficient numbers of neurological patients to ensure the ability of students to pursue that discipline. 
In the spring of 1924, Dr Edvards Kalniņš (1869-1949) was elected as a docent in neurology. The two departments worked very closely together in research and in the establishment of the Latvian Association of Neurologists and Psychiatrists (1924). Although the two sectors were kept apart in academic terms, nearly all practicing psychiatrists chose to define themselves as "specialists in nervous and mental disorders."

The Department of Psychiatry first delivered lectures to fourth-year students during the spring semester of 1922. The lectures were delivered in Latvian by Buduls as head of the department. A sixth year of studies was added for medical students in the 1922/1923 academic year, with general psychiatry being taught during the fifth year and clinical psychiatry being taught during the sixth year. This curriculum remained unchanged until 1930, when Buduls, then a dean of Faculty of Medicine, suggested that the plan be amended to strengthen training in clinical areas. Once the new plan was in place, lectures in psychiatry were delivered during the fifth year, with practical activities in the field of psychiatry occurring during the sixth year - a two-week clinical cycle with six hours of work every day. Students were divided up into groups to study practical aspects of clinical psychiatry. The new programme that was introduced in 1930/1931 remained unchanged all the way up until World War II.

The lack of academic traditions in the early years of the existence of the University of Latvia created major problems. All faculty members had studied in foreign languages, mostly in Russian and German, and that meant an absence of scholarly terminology in Latvia. The study of psychiatry and other disciplines of medicine involved a lack of specialised terminology in Latvian. Work on creating psychiatric terminology was different than was the case in 
other areas of medicine, because psychiatrists work with the human psyche, which is very difficult to describe. The first and most difficult job for Buduls was to name and define the psychic functions of human beings. Most of the abstract concepts were derived from words in German, and Buduls defined the concepts. The complexity of this process is seen in the fact that a lecture that was delivered in the 1941/1942 academic year still used words from the German language to describe normal psychological phenomena even though the Latvian language had been spoken in the sector for twenty years. Terminology of psychopathology was based on "medical languages" - Latin or Greek. Buduls kept most of those terms unchanged, though he did adapt them to the laws of Latvian grammar. After two years of delivering lectures to medical students, Buduls released the textbook "Psychiatry: General Aspects" in 1924, doing so after tireless work on the relevant terminology. In 1925, the book received an award from the Latvian Cultural Fund. Five years later, in 1929, Buduls published the second volume of the book, "Psychiatry: Special Aspects." 65 years later, Professor Imants Eglītis (1938-1997) said that most of the terms defined by Buduls in the area of psychiatry have withstood the test of time and are still being used today.

Professor Buduls also defined areas of research work at the Department of Psychiatry at the University of Latvia. Research focused on hereditary aspects of mental diseases, epidemiology, biochemistry, and the clinical testing of the latest therapeutic methods in Latvia.

The work on congenital diseases began in 1926, when the Department of Psychiatry announced a research paper competition for students in this area, asking them to "study the psychic degeneration and regeneration of a family." Student Verners Kraulis, who would go on to become a private docent and one 
of the most vivid personalities in inter-war psychiatry, wrote a descriptive genealogical study about the heredity of mental diseases in three dynasties of Baltic Germans who had lived in the Baltic States for centuries. Presumably this study was the decisive factor in Kraulis' ongoing interest in the theory of heredity. His dissertation was titled "On Hysterical Reactions and their Constitutional Foundations" (1931). His post-doctoral work led to the publication of the thesis "On Hereditary Relations between Cyclophrenia and Schizophrenia: Psychotic Brothers and Sisters, Parents and Children at Latvia's Psychiatric Hospitals" (1938). Issues of heredity in terms of eugenics were also discussed extensively by Kraulis in various popular articles. He was also involved in the work of the Biochemistry Laboratory of the Department of Psychiatry, where he conducted serologic studies of syphilis in patients suffering from progressive paralysis. Kraulis studied the level of bromine and iodine in the blood, as well as changes in the surface tension of urine in patients with mental diseases. He obtained international recognition for the development of modified insulin shock therapy.

Jānis Vilde wrote the second dissertation at the Histological Laboratory of the Department of Psychiatry, though he became a private docent in neurology, not psychiatry. He conducted post mortem analysis of patients with progressive paralysis to publish the thesis "Pathological Anatomy of Changes in the Brains of Paralytics after Malaria Therapy" (1939).

Alongside the aforementioned areas of research, the department's clinic also tested the latest clinical therapy methods. Beginning in 1923, specialists at the Sarkankalns Hospital began to treat progressive paralysis caused by syphilis with malaria fever therapy (Jauregg, 1917). In 1936, it began to use insulin shock (Sakel, 1933) and cardiazol (pentylenetetrazol) convulsive therapies 
(Meduna, 1934). The university clinic also organised courses at which physicians from other hospitals could learn the methods.

The further scientific and clinical development of psychiatry in Latvia was most influenced by the German school of psychiatry which dominated in Europe in the early $20^{\text {th }}$ century. Most faculty members at the Department of Psychiatry of the University of Latvia spent time at psychiatric clinics and research centers in Germany and Austria, particularly in German Psychiatric Research Institute in Munich, which was undeniably the global epicentre for psychiatry in the 1920s. Most Latvian doctors published international papers about psychiatry in German medical journals.

Apart from the Department of Psychiatry, the most fruitful scholarly work was done at the Ģintermuiža Hospital, which competed seriously with the university's clinical base at the Sarkankalns Hospital in terms of published papers. This is down to the fact that the Gintermuiža Hospital, like the Sarkankalns Hospital, had only one director during the entire inter-war period Kristaps Neibergs (1875-1950), who supported the scholarly efforts of his employees.

The Ģintermuiža Hospital also established laboratories for serological (1926) and anatomical examinations (1927). The serological research was led by Dr Rihards Verners (1888-?), while the anatomic research was directed by Vladimirs Nikolajevs (1903-1975). The Ģintermuiža serological laboratory observed trends of the era, researching syphilis and progressive paralysis just like the university clinic was doing. In 1933, research began in terms of the examination of the permeability of the hematoencephalic barrier in psychiatric patients. This made it possible for doctors to propose hypotheses on etiology and pathological process of schizophrenia. Nikolajevs, who was a student of 
Buduls, defended a dissertation in 1937, "On the Relationship between the Liver and the Brain," and this can be seen as the most important result of scientific work done at the Ģintermuiža hospital.

An evaluation of the work of the Department of Psychiatry at the University of Latvia during the inter-war period makes it possible to conclude that it created firm foundations for the first generation of Latvian psychiatrists. Latvian psychiatrists mostly recognised the neurogenic aspects of etiology and pathogenesis of mental disorders, following the trends in biologically orientated school of psychiatry. Theories about psychoanalysis were put to use in Latvia, but they were not a part of the interests of academic psychiatry. At a time when theoretical psychiatry in the world began to split up into two areas, arguing about the psychogenic or neurogenic nature of psychiatric diseases, Latvian psychiatry chose to belong to the somatically focused school of psychiatry. 


\section{CLINICAL PSYCHIATRY}

Precise data about the number of physicians employed in various fields of medicine in Latvia can be found only starting from 1930, when there were new rules about the registration of physicians and the permission to use the title of "specialist". The rules said that each doctor registered with the Health Department could practice in any area of medicine, while the title of "specialist" was available only for those physicians who had been specifically trained in one area or another. The Health Department registered ten areas of specialisation, including "nerve diseases and psychiatry" as a combined speciality. Special training in the field of psychiatry and nerve diseases meant that after graduation, doctors had to spend two years working for the relevant university clinic or wards at other hospitals which were recognised by the Health Department. In 1930, the hospitals which were declared to be qualified for the training of psychiatrists were the Alexander Heights Hospital, the Sarkankalns Hospital, and the psychiatric hospitals at Strenči, Ģintermuiža and Daugavpils. In 1937, the same rights were given to the psychiatric ward at the Liepāja City Hospital.

In 1930, there were 39 registered doctors in the field of nerve and mental diseases. No doctor defined himself exclusively as a psychiatrist, which indicates that the disciplines of psychiatry and neurology were very closely linked during the inter-war period. At the beginning of World War II, only three physicians had registered themselves as psychiatrists. The largest number of psychiatrists and psychiatrists- neurologists was seen in 1935, when 51 specialists of this type were registered. Most of them - 34 specialists - were employed by the five major hospitals, the psychiatric wards at the Liepāja City 
Hospital and the Rīga No. II City Hospital, and the two Šēnfelds clinics. The other physicians treated patients on a private basis, worked at nerve disease clinics, or were employed by other types of health care institutions which were not directly involved in psychiatry. In 1936, the Health Department registered 16 areas of specialisation in medicine, and in this case psychiatry was registered separately from nerve diseases. It was still possible, however, to register in relation to two related sectors. Among the five listed and related areas of specialisations were "nerve diseases and psychiatry." It must be added that in 1936 there were differences between doctors who "accept N diseases" and "specialists". In the former case the issue related to doctors in specific areas of medicine who had universal knowledge about the outpatient treatment of diseases. In the latter case, these were doctors who had worked for several years at the clinics of the Faculty of Medicine so as to gain the theoretical and practical knowledge that is necessary for clinical work. This new system also spoke to different amounts of time which people had to spend in residency. A doctor who "accepts $\mathrm{N}$ diseases" had to spend at least two years in residency in the field of psychiatry, while specialist doctors had to spend four years in the process. In those cases in which the physician chose a combined area of specialisation, the residency had to be full time in one sector and at least part time in the other one. During the entire training period, the doctor was supervised by a specialist physician.

The nomenclature of disease is another area in which precise data are only found beginning from 1931, when the government approved instructions on the use of the international disease nomenclature. Beginning from 1931, the International List of Causes of Death was used in Latvia to prepare mortality statistics. Prior to that, Russian treatment rules had been in effect in Latvia for a 
long period of time, and it is likely that psychiatrists used the nomenclature of mental diseases that was established at the $2^{\text {nd }}$ meeting of psychiatrists in Kyiv in 1905 and took effect in the Russian Empire in 1907.

Because the nomenclature that was adopted in Latvia in 1931 was primarily focused on statistics related to the cause of death, there were no separate sections related to mental or psychiatric diseases. Psychiatric diagnoses in this classification were listed under several sections of the nomenclature. The same nomenclature, with a few additions, was also used for morbidity statistics. On January 1, 1940, the revised International List of Causes of Death took effect in Latvia, as adopted in Paris in 1938.

Statistical data about the frequency of inpatient diagnoses between 1927 and 1938 show that more than $60 \%$ of psychiatric inpatients were in hospital for reasons of schizophrenia. Other diagnoses included mental retardation at various levels of severity, manic depression, epilepsy and progressive paralysis, but these diagnoses were far fewer in numbers. The other inpatient diagnoses were often at a level of $2 \%$ or less.

When it came to the treatment of mental diseases in the early 1920s, there was a visible involvement of so-called therapeutic nihilism. Nearly all of the psychiatric diseases were seen as untreatable or only treatable with symptomatic therapy. Among the treatment methods used at psychiatric hospitals were labour therapy, hydrotherapy involving long periods in bathtubs, as well as pharmacotherapy, which the physicians characterized in the best case for symptomatic treatment and in the worst case as medical straitjackets.

The situation in psychiatry changed when so-called biological or somatic treatment methods appeared in clinical practice. Malaria fever therapy was used to treat progressive paralysis, and shock therapy was introduced to 
treat schizophrenia. This created hopes that formerly untreatable progressive paralysis and schizophrenia could be treated after all.

Following along with the latest discoveries in the global world of psychiatry, malaria fever therapy began in Latvia in 1923, followed by insulin and cardiazol shock therapy in 1936. The use of malaria fever therapy in Latvia began six years after its origins at a psychiatric clinic in Vienna, which was largely because the method originated during World War I, thus delaying its further distribution. The shock therapy methods that were originated in 1933 and 1934 appeared in Latvia in late 1936.

Malaria fever therapy did not require special inventory or specifically trained personnel at psychiatric hospitals, but shock therapy made it clear quite quickly to doctors that such complicated treatment methods could not be organised in the usual wards of psychiatric hospitals. Work began on organizing specialised insulin wards. Insulin therapy required specific medical equipment, a wide range of medications, isolated and well-appointed wards, and specially trained doctors, nurses and caretakers. Shock therapy received major support from the Health Department, which believed that its introduction at clinics would speed up "the movement of patients." To a certain extent, the government even pressured doctors to introduce the method. The popular press also was very enthusiastic about the new therapy.

There are only a few publications about the results of somatic therapeutic methods in clinical practice in Latvia. There is one about the use of malaria fever therapy, and there are five papers about the use of insulin or insulin/cardiazol therapy.

The paper about the use of malaria fever therapy dealt with 50 patients suffering from progressive paralysis at the Sarkankalns Hospital. The published 
results were very poor. Only $4 \%$ of those who were treated regained their ability to work, while $14 \%$ died during the therapeutic process. The results of insulin and cardiazol shock therapy, by contrast, were very promising. The Sarkankalns Hospital reported that $69.8 \%$ of 53 schizophrenics who had been treated over the course of ten months had regained their working abilities, while the Gintermuiža Hospital reported about 98 patients who were treated over the course of 17 months; $46 \%$ of them were cured and discharged from hospital.

Insulin shock therapy also relates to an event which ensured international recognition for Latvian psychiatry. In Sarkankalns Hospital a modified insulin shock therapy method (prolonged or protracted shock) was introduced - one which was elaborated by Verners Kraulis and received approval from the originator of insulin shock therapy, the Austrian psychiatric Manfred Sakel. Kraulis was among the first (and perhaps the very first) specialist to implement the prolonged shock as treatment method, and he published papers about it in European and American psychiatric journals.

The shock therapies seemed to be so promising that the International Congress of Psychiatrists which took place in Bern in the spring of 1937 was devoted entirely to the new somatic therapies. Latvian psychiatrists attended the congress, too - along with Kraulis, the Sarkankalns Hospital delegated Saltups to the event, and it is thought that Nikolajevs from the Gintermuiža Hospital was also there. The Latvian doctors were not at the event as listeners, either. Three of the 67 reports were presented by the aforementioned doctors. Publications from the congress make it difficult to determine the extent to which the Latvian psychiatrists attracted attention, but it is clear that Latvian psychiatrists had successfully joined the international circles of their profession. 
A review of papers published by psychiatrists in the 1920s and 1930s about the use of somatic treatment methods leads to the conclusion that they are difficult to interpret and do not offer a full understanding of how the methods worked and how effective and safe they were. These were empirical treatment methods which were not based on modern principles of evidence-based methods. It is quite possible that the optimism of the doctors led to a situation in which failures were hushed up and positive results were emphasised. Without taking an in-depth look at the ethical problems of malaria and shock therapy and without analysing their true effects in the treatment of psychiatric disorders, one can say that the introduction of the methods in the world of psychiatry offered certain benefits and changed Latvian psychiatry as such so as to conclude the process of medicalization that began in the latter half of the $19^{\text {th }}$ century.

When we look at the benefits of malaria fever therapy, it has to be said that this reduced therapeutic nihilism at hospitals. The cause and possible treatment of one major psychiatric disorder were determined. Hospitals actively set up serologic laboratories for investigations and research.

Shock therapies changed the role of psychiatric hospitals to an even greater extent. Insulin wards were comparable or even superior to the somatic inpatient wards of hospitals in terms of equipment and personnel. The use of shock therapy at psychiatric hospitals brought psychiatry closer to the rest of medicine, also offering positive stimuli to psychiatrists themselves. Instead of working as supervisors and adjusters of behaviour, they became "real" physicians, and the psychiatric hospitals turned from something similar to shelters into true medical centres. Papers published by psychiatrists in Latvia in 
the 1920s and 1930s went into great detail about how psychiatric hospitals rid themselves of the reputation of shelters.

Inpatient indicators also changed along with the understanding that progressive paralysis and schizophrenia could be treated. In the 1920s, the main indicator for inpatient treatment was that the patient was "dangerous to his or her surroundings." By the late 1930s, in contrast, the main indicator was "the possibility of active treatment."

The final important benefit is the fact that doctors started to inform the relatives of the patients and ask for their permission to begin the treatments, which seem to be the first documented cases of informed consent in the history of psychiatry in Latvia. 


\section{THE ROLE OF PSYCHIATRY IN SOCIAL PROCESSES}

Characteristic of the inter-war period in Latvia was the fact that medical professionals were of great importance in social processes, not least in terms of projects aimed at improving public health. Doctors, including psychiatrists, often began to see themselves as responsible not just in terms of their individual patients, but also in terms of society, the nation, and even humanity as a whole. Several medics joined the eugenics movement, which was part of the Zeitgeist in the first half of the $20^{\text {th }}$ century. The popularity of eugenics increased throughout the world during the first decades of the century, promoting the idea that people with congenital diseases should refrain from having children (negative eugenics) while, at the same time, facilitating the extent to which physically and mentally healthy people engage in reproduction. So-called sterilisation laws were adopted in several European countries in the late 1920s and during the 1930 s so as to reduce the number of "eugenically unworthy" individuals.

The Latvian state joined the eugenics movement comparatively late only in the latter half of the 1930s, during the authoritarian regime of Kārlis Ulmanis (1934-1940). At that time concerns about demographic crisis became a public debate. Government focused mainly on so-called "positive" direction of eugenics, still acknowledging the need to enhance not just the quantitative, but also the qualitative growth of the population.

Research and implementation of eugenics in Latvia during the inter-war period relates to two institutions - the Institute of the Living Force of the Nation, which was set up under the wing of the Health Promotion Society in 
1938, and the Eugenics Commission of the People's Welfare Ministry. Two psychiatrists took part in the work of these institutions. The more active of them was Docent Verners Kraulis, who joined the Eugenics Commission in 1938 and also became head of the Eugenics Department of Institute of the Living Force of the Nation. Kraulis taught at the University of Latvia, and during the autumn semester of 1939, he offered lectures on the subject of eugenics. In March 1939 the director of the Gintermuiža Hospital, Kristaps Neibergs, in turn, became a director of the Marriage and Heredity Advice Centre - a new branch of the Institute of the Living Force of the Nation.

There was a debate about the need for a sterilisation law and about the groups of people who should be subject to such a law in the 1930s in Latvia, thus following along with the experience of other countries in this regard. Among those to be declared "eugenically unworthy" were people with hereditary diseases, including mental diseases; they were seen as individuals who endangered society. Most psychiatrists who offered public opinions about the mental disorders that were seen as hereditary and thus subject to the sterilisation law included oligophrenia in the mix. They were more reticent about schizophrenia, manic depression and epilepsy, all of which were included in the radical sterilisation law that was adopted in Nazi Germany in 1933. Latvian psychiatrists argued that if a sterilisation law was to be introduced, then it should only be applied to patients who could be expected to leave inpatient facilities, but not to those who spent their entire lives in hospital. Rejecting the theoretical justification for eugenics in Germany, Latvian doctors discussed the need for a sterilisation law not in terms of the need to preserve "racial purity," but instead on the basis of possible social benefits. 
After a period of debate, the Latvian government drafted regulations about sterilisation, including them into a new Medical law that was adopted in 1937. The law took force on January 1, 1938, thus enshrining the practice of eugenics into Latvian law. The law spoke to the establishment of a specialised Eugenics Commission which would deal with eugenics issues, as well as the issuance or denial of permits for abortions and sterilisation. Abortions without the permission of the commission were banned, apart from a few instances that were specifically listed in the law.

The Medical law said that permission for an abortion could be requested from the Eugenics Commission by the relevant individual if she was 21 or older, her parents or guardians if she was under 21 , and by caretakers in case of those women who were declared to be mentally ill.

Hereditary mental and somatic disorders which would be subject to eugenics were not listed precisely in the law on medical treatment, leaving such decisions up to the Eugenics Commission. The commission was allowed to issue a permit for abortion or sterilisation to individuals "who suffer from hereditary or acquired mental or difficult physical diseases, if there are indications that they might be transferred to successors and if there is no hope for recovery." It is very important here to emphasise the fact that unlike several other countries, Latvia did not engage in forced sterilisation. The law permitted abortions and sterilisation only on the basis of voluntary agreement.

The Eugenics Commission was made up of a chairman (the director of the Health department), and three members - two doctors and one judge or prosecutor. The Minister for People's Welfare appointed psychiatrist Verners Kraulis as one of the doctors on the commission in 1938. This was logical. Kraulis had written about eugenics in the popular press on more than one 
occasion, and he was one of the most educated doctors in Latvia in the area of genetics after studying the relevant research methods at the German Institute for Psychiatric Research under the tutelage of Ernst Rüdin. Kraulis wrote his dissertation and his post-graduate paper there on the subject of the heredity of mental diseases.

Data about the number of patients who were examined by the Eugenics Commission and about its findings are only available from 1938 and 1939. There were 106 meetings to consider 943 individuals. Sterilisation permits were approved for 59 women and three men. Abortions were permitted in 654 instances (though that number differs a bit in various sources).

These data do not offer information about the reasons why sterilisation or an abortion were permitted, nor do they tell us about the extent to which people with mental disorders were subject to the process. Neither can we precisely reconstruct the number of mentally disordered people who came to the attention of the Eugenics Commission. The available data suggest that they were comparatively few in numbers.

It is clear that the inter-war Eugenics Commission was basically a mechanism which was aimed at reducing the number of abortions on the basis of social indications. The great majority of people who were examined by the Eugenics Commission in 1939 were there to ask for a permission for abortion due to somatic indications $-43 \%$ in relation to women with tuberculosis, $28 \%$ for women with heart disorders, and $6 \%$ for abortions related to mental disorders. Most of the sterilisation permits, in turn, were issued to people with mental diseases. Of 29 that were issued in 1939, 28 related to "mental disorders and defects". We can assume that the situation during the entire period of the Eugenics Commission (1938-1941) was similar to that which was seen in 
1939. Proportionally few mental patients were sent to the Eugenics Commission, but almost all of them were given sterilisation permits.

Documents from the Latvian State Historical Archives show that the People's Welfare Ministry strictly observed the declared principle of voluntarism in this process, but the rule that legally appointed guardians of a mentally disordered woman must approve the process of abortion was not always considered. Often the relatives of mentally disordered women approached the Eugenics Commission when the relevant woman was already pregnant. If the woman did not have a court-appointed guardian, the Eugenics Commission was satisfied with the agreement of the woman herself if there were also requests from her relatives or the relevant local government. In the case of sterilisation permissions, the commission first demanded the appointment of a guardian, and only then gave the permission.

Along with the practice of eugenics, theoretical research in the field began in Latvia after the Eugenics Department of the Institute of the Living Force of the Nation was established and Verners Kraulis became its director. One of the first jobs for the department was to determine the prevalence of mental disorders in Latvia, and Kraulis led a team of researchers who focused on the prevalence of mental retardation in the country.

Kraulis used the proband method, considering defective children in orphanages in Rīga to be the first probands. The study focused on 41 families with 1,200 individuals, looking at the role of heredity in the origins of oligophreny. Kraulis concluded that the families of oligophrene probands had nearly two times more children than the average in the country, as well as that such families had approximately 16 times more "unworthy individuals" than the average in the population. 
In January 1940 Eugenics Commission prepared new regulations on the declaration of mental diseases and congenital physical abnormalities. The aim was to continue to identify and study the prevalence of mental and hereditary diseases in Latvia. The rules were mandatory for all psychiatric hospitals, psychiatrists and practicing doctors.

Another goal of the Eugenics Department was to increase the number of physically and mentally healthy newborns in Latvia. The aforementioned Marriage and Heredity Advice Centre was established in Rīga in March 1939 at the initiative of Kraulis and Jēkabs Prīmanis. Its director was the psychiatrist Kristaps Neibergs, and the centre offered advice to people who wanted to get married, but first wanted to make sure that their health would not endanger their spouse and that there were no hereditary diseases that were of concern. There were also consultations on various complications in married life. During its first year, the centre provided consultations to 217 individuals, also sending written responses to people outside of Rīga. Most of the consultations related to infertility and family conflicts.

The life of the Institute of the Living Force of the Nation was short; it was shut down in September 1940 after the establishment of the Soviet regime in Latvia. The Eugenics Commission, in turn, remained in place after the Soviet invasion. It was shut down after the Germans invaded in the summer of 1941, but in January 1942 it was reinstated.

Eugenics began as a genetic and social movement, but the Nazis completely discredited it by utilising radical practices such as euthanasia of literally hundreds of thousands of psychiatric patients between 1940 and 1945 . It is customary in Latvia to refer to the murder of mentally ill people as an example of "Nazi barbarism" - most of the patients of the country's psychiatric 
hospitals were killed during the Nazi occupation. It is completely clear that the Latvian governance institutions that were in place at that time and, even to a greater extent, the country's psychiatrists could not have been able to prevent this tragedy. It is true that Latvian psychiatrists who wrote about eugenics never once suggested that the murder of untreatable patients could be acceptable, but it must be admitted that during the inter-war period, Latvian psychiatrists did take part on the theoretical and practical eugenics movement in which mentally disordered people were declared to be "unworthy." 


\section{CONCLUSIONS}

In evaluating the development of psychiatry in Latvia between 1918 and 1940, it must first be emphasised that it must be seen as a separate phase in the overall history of psychiatry in the country, because after World War II the existing school of psychiatry basically was eliminated.

1. In describing psychiatry as a component of the health care system during the inter-war period, it must be concluded that this was a period in which institutionalised psychiatry flourished, as seen in the ongoing expansion of inpatient treatment facilities for psychiatric patients. Despite the efforts of the state, local governments, psychiatrists and the public to deal with problems in this area, access to psychiatric care remained difficult throughout the entire period, with the hospitals themselves always having too many patients. This was mostly down to poorly organised social care for psychiatric patients.

2. In evaluating psychiatry as an academic discipline, it must be concluded that it developed in Latvia on the basis of examples set by biologically focused schools of psychiatry in Western Europe, and this was fully in line with the spirit of the age in global psychiatric studies. Scholarly papers presented all of the main theories and practices in the biologically focused school of psychiatry - ones which dominated during the first half of the $20^{\text {th }}$ century - the last decades before the introduction of psychopharmacological treatments in practice.

3. When it comes to clinical practice, psychiatrists in Latvia offered the most modern and timely treatment methods of the age - malaria fever therapy beginning in 1923 and insulin and cardiazol shock therapy in 1936. The introduction of somatic treatment methods at Latvia's clinics led to hopes that 
patients with progressive paralysis and schizophrenia who had been seen as untreatable in the past could be cured after all, thus concluding the medicalization process in psychiatry which began in the latter half of the $19^{\text {th }}$ century.

4. The role of psychiatry in social processes could be observed throughout the inter-war period. Some psychiatrists worked to facilitate public health by publishing many articles in popular publications and the press. They also took part in the eugenics movement that was of significance in the world in the 1930s. Although the eugenics law that was adopted in Latvia in the late 1930s was theoretically aimed at reducing the number of mentally disordered people, the fact is that the number of such people who were subject to eugenics was small.

An overall evaluation of the development of psychiatry in Latvia during the inter-war period shows that the Latvian school of psychiatry existed for no more than a quarter-century, but it was in lockstep with trends in the development of psychiatry in the world. Although psychiatric care in Latvia was often problematic because of poor social care for psychiatric patients, people with mental disorders at least theoretically had access to psychiatric medical care that satisfied the standards of the Western world. 


\section{AUTHOR'S PUBLICATIONS}

\section{Scientific publications related to the topic of the doctoral theses}

1. Lībiete, I. Psihiatriskās aprūpes problēmas Latvijā 20. gs. 20.-30. gados. Acta Medico - Historica Rigensia, Nr.10. ACCPTED FOR PUBLICATION

2. Lībiete, I. Verners Kraulis (1904-1944) - spilgta personība Latvijas psihiatrijas vēsturē. Latvijas Universitātes Raksti. Zinātņu vēsture un muzejniecība, Nr.780, 2012, 182.-195. lpp.

3. Lībiete, I. Fighting Schizophrenia: Beginnings of Somatic Treatments in Psychiatry in Riga Sarkankalns Hospital in the 1930s. Baltic Journal of European Studies, vol.1, No.1(9), 2011, pp. 257-268.

4. Lībiete, I. Latvijas Universitātes Psihiatrijas katedras izveide un darbība 20. gs. 20. gados. Latvijas Universitātes Raksti. Zinātņu vēsture un muzejniecība, Nr.763, 2011, 54.-64. lpp.

5. Lībiete, I. Latvijā pirmā psihiatriskā kolonija ārsta A. Laksberga atmin̄ās. Acta Medico - Historica Rigensia, Nr.9, 2010, 368.-375. lpp.

\section{Publications in abstracts of scientific conferences related to the topic of the doctoral theses}

1. Lībiete, I. Kokaīnisti un morfinisti ārstu praksē Latvijā 20. gs. 20.-30. gados. RSU 2014. gada zinātniskā konference. Tēzes, Rīga, 2014, 484. lpp.

2. Lībiete, I. Latvijas lauku iedzīvotāju iesaiste psihiatriskās aprūpes nodrošināšanā 20. gadsimta 30. gados. Lauku ārstniecība Latvijā: atskats un vērtējums. Medicinas vēstures simpozijs 2013. gada 18. septembrī. Tēzes un raksti, Rīga, 2013, 61.-62. lpp.

3. Libiete, I. Psychiatry and Eugenics in Latvia During the Interwar Period. EAHMH Conference Risk and Disaster in Medicine. Book of abstracts, Lisbon, 2013, pp. 48-49.

4. Herzog, U., Libiete, I., Salaks, J. Use of Max Cloetta's Narcotic Solution for Prolonged Sleep Therapy in Latvia in the 1930s. RSU 2013. gada zinātniskā konference. Tēzes, Rīga, 2013, 460. lpp.

5. Libiete, I. Brain Studies in University of Latvia between World Wars. ISHN $17^{\text {th }}$ Annual Meeting Abstract Book, Venice, 2012, p. 78.

6. Libiete, I., Olsena, S. Ethical and Legal Aspects of Preserving and Exhibiting Materials about the History of Psychiatry in Museums. Abstracts of the XXV International Baltic Conference on the History of Science, Vilnius, 2012, pp. 36-37. 
7. Lībiete, I. Psihiatriskās aprūpes pieejamība Latvijā 20. gs. 20.-30. gados. RSU 2012. gada zinātniskā konference. Tēzes, Rīga, 2012, 497. lpp.

8. Lībiete, I. Взаимодействие Российской школы и Европейских традиций в становлении и развитии психиатрии Латвии. Бюллетень Национального научно-исследовательского института общественного здоровья. Материаль Международного симпозиума „,Традиции и новаторство в истории отечественной медицины”, Мосkва, 2011, с. 104-105.

9. Либиете, И. Психиатрическая помощь в Латгалии в 20-30-ые годы XX столетия. Материаль научной конференции „Проблемь общественного здоровья, здравоохранения, сестринского дела и истории медицины”", Гродно, ГрГМУ, 2010, с. 124-125.

10. Lībiete, I. No patversmes līdz palātai: izmaiņas psihiatriskajā aprūpē Latvijā 20. gs. 30. gados. RSU 2011. gada zinātniskā konference. Tēzes, Rīga, 2011, 452. lpp.

11. Lïbiete, I. Fighting schizophrenia: beginnings of somatic treatments in Riga Sarkankalns hospital in the 1930's. Abstracts of the $24^{\text {th }}$ International Baltic Conference on the History of Science, Tallinn, 2010, pp. 47-48.

12. Lībiete I. Sifiliss, dementia paralytica un malārijas drudža terapija Latvijas psihiatru praksē 20. gadsimta 20. gados. RSU 2010. gada zinātniskā konference. Tēzes, Rīga, 2010, 443. lpp.

\section{Presentations at conferences related to the topic of the doctoral theses}

1. RSU 2014. gada zinātniskā konference. Rīga, 2014. Kokaīnisti un morfinisti àrstu praksē Latvijā 20. gs. 20.-30. gados.

2. Lauku ārstniecība Latvijā: atskats un vērtējums. Medicīnas vēstures simpozijs 2013. gada 18. septembrī. Rīga, 2013. Latvijas lauku iedzīvotāju iesaiste psihiatriskās aprūpes nodrošināšanā 20. gadsimta 30. gados.

3. EAHMH Conference Risk and Disaster in Medicine. Lisbon, 2013. Psychiatry and Eugenics in Latvia during the Interwar Period.

4. RSU 2013. gada zinātniskā konference. Rīga, 2013. Use of Max Cloetta's Narcotic Solution for Prolonged Sleep Therapy in Latvia in the 1930s.

5. LU 71. zinātniskā konference. Zinātņu vēstures un muzejniecības sekcija. Rīga, 2013. Profesors Hermanis Buduls un zinātniskās terminologijas veidošana psihiatrijā 20. gs. 20.-30. gados.

6. ISHN $17^{\text {th }}$ Annual Meeting. Venice, 2012. Brain Studies in University of Latvia between World Wars. 
7. XXV International Baltic Conference on the History of Science. Vilnius, 2012. Ethical and Legal Aspects of Preserving and Exhibiting Materials about the History of Psychiatry in Museums.

8. RSU 2012. gada zinātniskā konference. Rīga, 2012. Psihiatriskās aprūpes pieejamība Latvijā 20. gs. 20.-30. gados.

9. LU 70. zinātniskā konference. Zinātnuu vēstures un muzejniecības sekcija. Rīga, 2012. Verners Kraulis - spilgta personība psihiatrijas vēsturē.

10. Международний симпозиум „Традиции и новаторство в истории отечественной медицины”. Москва, 2011. Взаимодействие Российской школь и Европейских традищий в становлении $u$ развитии психиатрии Латвии.

11. LU 69. zinātniskā konference. Zinātnuu vēstures un muzejniecības sekcija. Rīga, 2011. Psihiatrijas vēstures muzejs Ģintermuižā.

12. Научная конференция „Проблемы общественного здоровья, здравоохранения, сестринского дела и истории медицины”. Гродно, ГрГМУ, 2010. Психиатрическая помощь в Латгалии в 20-30-ые годы ХХ столетия.

13. RSU 2011. gada zinātniskā konference. Rīga, 2011. No patversmes lìdz palātai: izmaiņas psihiatriskajā aprūpē Latvijā 20. gs. 30. gados

14. $24^{\text {th }}$ International Baltic Conference on the History of Science. Tallinn, 2010. Fighting schizophrenia: beginnings of somatic treatments in Riga Sarkankalns hospital in the 1930's.

15. RSU 2010. gada zinātniskā konference. Rīga, 2010. Sifiliss, dementia paralytica un malārijas drudža terapija Latvijas psihiatru praksē 20. gadsimta 20. gados.

16. LU 68. zinātniskā konference. Zinātnuu vēstures un muzejniecības sekcija. Rīga, 2010. Psihiatrijas katedras darbība 20. gs. 20. gados. 


\section{REFERENCES}

\section{Unpublished sources}

\section{Sources}

1.1. The Latvian State Historical Archives

Fund of University of Latvia

LVVA, fund 7427, description 13, cases $281,784,1539,1902,793,705,862$.

LVVA, fund 7427, description 6, cases 393, 394, 398, 399, 405, 406, 407, 408. Fund of People's Welfare Ministry

LVVA, fund 4578, description 1, cases 202, 205, 204, 2578, 2481, 2491, 2492.

LVVA, fund 4578, description 4, cases 207, 208, 211, 404, 506, 507, 639, 640, 683.

Fund of Interior General Directorate's Health Department

LVVA, fund 1023, description 1, cases 47, 51, 54.

Fund of Rīga Sarkankalns hospital

LVVA, fund 2917, description 1, cases 2, 3, 4.

LVVA, fund 2917, description 3, cases 143, 238, 35, 203.

1.2. Pauls Stradins Museum of the History of Medicine archives

Stored collections of documents and manuscripts

Laksbergs, A. Autobiogrāfija (Autobiography). Manuscript. Fund 1, mvm1534.

Laksbergs, А. Первая психиатрическая колония в Латвие (First psychiatric colony in Latvia). Manuscript. Fund 1, case 8.

Laksbergs, A. Fašistu laaundarības Latvijā (The atrocities committed by Fascists in Latvia). Manuscript, 104 pages. Fund 1, case 40.

Laksbergs, A. Psihiatriskās slimnīcas vācu okupācijas laikā (Psychiatric hospitals during the years of German occupation). Manuscript, 126 pages. Fund 1, case 39.

Buduls lectures. Manuscript, 148 pages. Inventory nr.9700.

Buduls compiled program in psychiatry. Manuscript, 2 pages. Inventory nr.9717.

Students A. Ansons lecture records, academic year 1941/1942. Manuscript, 80 pages. mvm 43.621, R32.514.

Kraulis letter to Buduls. June 18, 1929. Manuscript, 1 page. mvm 45. 392. R.33.392.

Questionnaire filled by Kraulis. Manuscript, 1 page. mvm 45.393.

Announcements for meetings of Latvian Association of Neurologists and Psychiatrists. Fund 1, case 51.

Conference program. 1 page. Inventory nr. 11115. 


\section{Published sources}

2.1. Code of laws

Фрейберг, Н. Врачебно-санитарное законодательство въ Россіи: Узаконенія и распоряженія правительства по гражданской, медииинской, санитарной и фармацевтической частямъ, опубликованныя по 1 января 1913 года. 1913.

Starptautiskā nāves cēloņu nomenklatūra. Derīga 1940-1949. 1939.

\subsection{Transcripts of parliamentary debates}

Latvijas Republikas II Saeimas stenogrammas. II sesija. 1926. gads. Latvijas Republikas II Saeimas stenogrammas. VI sesija. 1927. gads. Latvijas Republikas III Saeimas stenogrammas. III sesija. 1929. gads. Latvijas Republikas III Saeimas stenogrammas. Ärkārtējā un IV sesija. 1929. gads.

Latvijas Republikas IV Saeimas Stenogrammas. VI sesija. 1933. gads.

$$
\text { 2.3. Statistical compendia }
$$

Tautas veselības statistika. (1927-1938).

Rìgas Pilsētas statistiskā gada grāmata. (1920-1924).

Latvijas medicīniskā personāla saraksts. (1923-1940).

Latvijas generālapgabala medicīniskā personāla saraksts 1943. gadam. 1943 Rokas grāmata 1946. gadam. 1946.

\subsection{Annual reports of University of Latvia}

Dāle, P. Vēsturisks pārskats par Latvijas Augstskolas nodibināšanu un vingas darbību pirmā (1919./20.) mācības gadā. 1921.

Latvijas Universitate divdesmit gados 1919-1939. II dala. Mācības spēku biogrāfijas un bibliogrāfija. 1939.

Latvijas Universitāte divdesmit gados 1919-1939. I daḷa. Vēsturiskas un statistiskas ziņas par universitāti un tās fakultātēm. 1939.

Latvijas Universitātes piecgadu darbības pārskats 1919-1924. 1925.

Latvijas Universitāte 1919-1929. 1929.

Latvijas Ūniversitātes divgadu darbības pārskats 1924-1926. 1926.

Latvijas Ūniversitātes darbības pārskats 1927/1928. 1928.

Latvijas Ūniversitātes darbības pārskats 1928/1929. 1929.

Latvijas Universitātes darbības pārskats 1929/30 akad. gads. 1930.

Latvijas Ūniversitātes darbības pārskats. 1930/31 akad. gads.1931.

Zinātne tēvzemei divdesmit gados 1918-1938. 1938.

Latvijas Universitātes lekciju un praktisko darbu saraksti. (1921-1940) 
2.5. Dissertations and habilitation thesis

Kraulis, V. Par ciklofrenijas un schizofrenijas hereditārām attiecībām.

Psihotiski brāḷi un māsas, vecāki un bērni Latvijas psīchiatriskās slimnīcās. 1937.

Kraulis, V. Par histērisko reakciju un vinas konstitucionāliem pamatiem. 1932.

Nikolajevs, V. Par aknu un smadzeņu attiecībām. 1936.

Vilde, J. Patologiski anatomiski pētījumi par lēpras slimnieku centrālo nervu sistēmu. 1930.

Будул, Э. Къ сравнительной рассовой психіатріи. 1914.

\subsection{Books and brochures}

Buduls, H. Latvijas galvas pilsētas Rīgas Sarkankalna slimnīcas vēsture 1862 $-1937.1938$.

Buduls, H. Nervu veselības kopšana skolas gados. 1931.

Buduls, H. Par alkoholismu. 1923.

Buduls, H. Poruka dvēseles noskañas krēslainās dienās. 1925.

Buduls, H. Poruku Jānis savas garīgās dzīves krēslainās dienās. 1911.

Buduls, H. Psichiatrija. Speciālā daḷa. 1929.

Buduls, H. Psichiatrija. Vispārīgā dą̧a. 1924.

Karlsons, Ž. Cilvēka ķermeņa ìpatnības un psīche. 1935.

Stradiņš, P. Veselības veicināšanas biedrības mērķi un uzdevumi. 1938.

Upners T. Eugēnikas nozìme tautas un valsts dzīvē. 1943.

Будул, Э. М. Къ статистикъ и этіологіи прогрессивнаго паралича. 1912.

\subsection{Articles in periodicals}

American Journal of Psychiatry (1938); Allgemeine Zeitschrift fur Psychiatrie und psychisch-gerichtliche Medicin (1927, 1933, 1936); Archiv für Psychiatrie und Nervenkrankheiten (1934, 1938); Ärstniecības Žurnāls (1942, 1943); Ārsts. Latvijas Ārstu Biedrības Žurnāls (1939, 1940); Brī̄ā Zeme (1936, 1937, 1938); Burtnieks (1931); Cīna (1940); Darbs (1940); Daugavas Vārds (1926); Daugavas Vēstnesis (1940); Iekšlietu Ministrijas Vēstnesis (1928, 1929, 1930); Jaunākās Ziñas (1936, 1937, 1939); Journal of Mental Science (1938); Journal of Molecular Medicine (1936); Juventus (1934);Latvijas Ārstu Žurnāls (1924, 1925, 1926, 1929, 1931, 1933, 1934, 1935, 1936, 1937, 1938, 1944); Latvijas - Igaunijas Biedrības Mēnešraksts (1938); Latvijas Kareivis (1928, 1929, 1931, 1932, 1933, 1934); Latvijas Sargs (1926); Latvijas Universitātes raksti (1926); Latvis (1926); Nākotnes Spēks (1924, 1925, 1928, 1930, 1933); Padomju Latvija (1940); Padomju Latvijas Ärsts (1940); Pašvaldības Balss (1939); Pašvaldības Darbinieks (1939,1940);Policijas Vēstnesis (1923); 
Psychiatric Quarterly (1938, 1942); Rìts (1936, 1937, 1939); Studenta Dzīve (1938); Students (1923, 1927, 1935);Studentu Dzive (1925); Tautas Labkläjības Ministrijas Mēnešraksts (1938, 1939, 1940); Tautas Veselība (1927, 1928); Tēvija (1942);Tieslietu Ministrijas Vēstnesis (1936, 1940);Valdības Véstnesis (1920, 1921, 1922, 1923, 1925, 1926, 1928, 1929, 1930, 1931, 1933, 1934, 1935, 1936, 1937, 1938, 1939, 1940); Virchows Archiv für pathologische Anatomie und Physiologie und für klinische Medizin (1937); Wiener Klinische Wochenschrift (1926); Zeitschrift für die gesamte Neurologie und Psychietrie (1928, 1931, 1933, 1937, 1938, 1939, 1941); Zemgales Balss $(1937,1939)$

2.8. Articles in occasional collections of scientific papers

Rakstu sakopojums Ģintermuižas slimnīcas (dib. 1887. gada 3. jūnijā) 50 gadu darbības atcerei. 1938.

I Latvijas Ārstu un Zobārstu Kongresa darbi. 1926.

Tautas dzīvā spēka pētǐšanas institūta raksti. 1939.

\section{Literature (historiography)}

Ackner, B., Harris, A., Oldham, A. J. Insulin treatment of schizophrenia: a controlled study. Lancet, vol.272, No.6969, 1957, pp. 607-611.

Alexander, F. G., Selesnick, S. T. The History of Psychiatry. A Fascinating Study of Psychiatric Thought and Practice from Prehistoric Times to the Present Day. New York : A Mentor Book, 1968. 573 pp.

Alks, Dz. Latvijas mediķi politisko represiju dzirnās 1940.-1953. Rīga : Rīgas Starptautiskais medicīnas zinātnes un farmācijas centrs, 1993. 102 lpp.

Anže, M. Medicīnas fakultātes absolventi - ārvalstu augstskolu profesori.

Latvijas Universitātei - 80. Konferences referātu tēzes, 1999, 153.-154. lpp.

Arājs, K. Latviešu kauli... Atmiņas par anatomikumu un antropologijas ziedu laikiem Latvijā. Rīga : Rīgas Stradiņa Universitāte, 2005. 279 lpp.

Baltiṇš, M. Medicīnas mācību grāmatu izdošana līdz 1944. gadam un LU mācības grāmatu apgāds. Latvijas Universitātes Raksti. Zinātņu vēsture un muzejniecība, Nr.639, 2001, 118.-126. lpp.

Baltiņš, M. Par privātdocenta statusu Latvijas Universitātē. Latvijas

Universitātes Raksti. Zinātņu vēsture un muzejniecība, Nr.653, 2003, 63.-79. lpp.

Bērziņš, V. (red.) 20. gadsimta Latvijas vēsture, II, Neatkarīgā valsts 1918 1940. Rīga : Latvijas vēstures institūta apgāds, 2003. 1022 lpp.

Bourne, H. The Insulin Myth. Lancet, vol.265, No.6793, 1953, pp. 964-968. 
Braslow, J. T. The Influence of a Biological Therapy on Physicians' Narratives and Interrogations: The Case of General Paralysis of the Insane and Malaria Fever Therapy, 1910-1950. Bulletin of the History of Medicine, vol.70, No.4, 1996, pp. 577-608.

Brown, E. Why Wagner-Jauregg Won the Nobel Prize for Discovering Malaria Therapy for General Paresis of the Insane. History of Psychiatry, vol.11, 2000, pp. 371-382.

Buduls, H. Prof. Dr. Med. Hermana Buduḷa Autobiogrāfija. Latvijas Ārstu un Zobārstu Apvienības Apkārtraksts, Nr.115, 1978, 28.-30. lpp.

Crammer, J. 1941-1950 // A Century of Psychiatry. Vol.1, Ed. by H.

Freeman et.al., London : Mosby-Wolfe Medical Communications, 1999, pp. $118-119$.

Crammer, J. A Basis of Biological reasearch // A Century of Psychiatry. Vol.1, Ed. by H. Freeman et.al., London : Mosby-Wolfe Medical Communications, 1999, pp. 132-134.

Doroshow, D. B. Performing a Cure for Schizophrenia: Insulin Coma Therapy on the Wards. Journal of the History of Medicine and Allied Sciences, vol.62, No.2, 2007, pp. 213-243.

Dorries, A., Beddies, T. The Wittenauer Heilstatten in Berlin: a case record study of psychiatric patients in Germany, 1919-1960 // The Confinement of the Insane. International perspectives. 1800-1965. Ed. by Porter, R., Cambridge : R., \& Wright, 2003, pp. 149-172.

Dowbiggin, I. The Quest for Mental Health: A Tale of Science, Scandal, Sorrow, and Mass Society. New York : Cambridge University Press, 2011. 248 pp.

Eglītis, I. Daži papildinājumi psihiatra R. Krūmiņa biogrāfijā. Latvijas Medicīnas augstskola. Rīga : AML, 1995, 33.-35. 1pp.

Eglītis, I. Dažu psihiatrijas (psihoterapijas) terminu veidošanas vēsturiskie aspekti. Medicinna. Vēsture. Valoda. Starptautiskās medicīnas vēsturnieku konferences un valodnieku simpozija referātu tēzes, 1993, 56.-57. 1pp.

Eglītis, I. Hermanis Buduls. Veselība, Nr.6, 1989, 4. lpp.

Eglītis, I. Jāņa Poruka slimība mūsdienu skatījumā. Latvijas Ārsts, Nr.1, 1991, 69.-73. 1pp.

Eglītis, I. Viena no pirmajām. Latvijas Ārsts, Nr.1, 1989, 55.-58. lpp.

Felders, B. Mazvērtīgo samazināšana - eigēnika Latvijā. Kultūras Diena, 2005, 23. apr., 16.-17. lpp. 
Fink, M. Origins of convulsive therapy // A Century of Psychiatry. Vol.1, Ed. by H. Freeman et.al., London : Mosby-Wolfe Medical Communications, 1999, pp. 96-98.

Freeman, H. et.al (Eds.) A Century of Psychiatry. Vol.1, London : MosbyWolfe Medical Communications, 1999. 183 pp.

Grāvere, R. Gastons Bakmanis (1883-1964). Medicīnas profesūra Latvijā: tapšana un attīstības tendences. Medicinnas vēstures simpozijs, 2009, 24.-25. lpp.

Grāvere, R. Izdevums „Nākotnes spēks”: medicīniskās sabiedrības devums bērnu profilaktiskajā veselības aizsardzībā (1920-1935). RSU 2011. gada zinātniskā konference. Tēzes, 2011, 451. lpp

Grāvere, R. Jānis Vilde un lībiešu antropolog̣ija. Latvijas Universitātes raksti. Zinātnu vēsture un muzejniecība, Nr.693, 2006, 152.-163. lpp.

Grāvere, R. Lībiešu antropologijas pētniekam Jānim Vildem - 105. Latvijas Vèstures institūta žurnāls, Nr.3, 2005, 125.-136. lpp.

Grāvere, R. Tieslietu mediķim Jānim Koceram - 110. Latvijas Ārstu un Zobārstu Apvienības Apkārtraksts, Nr.159/160, 2011, 39.-40. 1pp.

Healy, D. Some continuities and discontinuities in the pharmacotherapy of nervous conditions before and after chlorpromazine and imipramine. History of Psychiatry, No.11, 2000, pp. 393-412.

In memoriam. Profesoru Dr. med. Nikolaju Jerumu pieminot. Latvijas Ārsts, Nr.4, 1991, 9. lpp.

Kragh, J. Malaria fever therapy of the insane in Denmark. History of Psichiatry, Nr.21(4), 2010, pp. 471-486.

Kragh, J. Shock Therapy in Danish Psychiatry. Medical History, vol.54, No.3, 2010, pp. 341-364.

Kuzṇecovs, V. 19. gadsimta pirmās puses valsts iestādes garīgi slimiem Latvijā: Aleksandra Augstumu personāls un pacienti - II daļa: pacienti. $L U$ raksti. Zinātñu vēsture un muzejniecība, Nr.763, 2010, 146.-167. lpp.

Kuzṇecovs, V. 19. gs. pirmās puses valsts iestādes garīgi slimiem Latvijāa: Aleksandra augstumu personāls un pacienti - I daļa: personāls. LU raksti. Zinātņu vēsture un muzejniecība, Nr.738, 2008, 78-97. lpp.

Kuzṇecovs, V. 19. gs. pirmās trešdaļas vājorātāgo aprūpe Latvijā: principi, iestādes, personas. LU raksti. Zinātņu vēsture un muzejniecība, Nr. 716, 2007, 122.-132. lpp. 
Kuznecovs, V. Abolishment of the Military Guard at the Riga Alexander Heights Institution in 1856: War as a Monitor of Humanization. Baltic Journal of European Studies, vol.1, No.1(9), 2011, pp. 269-281.

Kuzṇecovs, V. Psihiatriskās aprūpes sākumi Latvijāa: Aleksandra Augstumu slimnīcai - 180. LU raksti. Zinātņu vēsture un muzejniecība, Nr.693, 2006, 137.-144. 1pp.

Kuznecovs, V. The history of psychiatry in Latvia. Acta Medico-Historica Rigensia, Nr.2, 1994, 137.-152. lpp.

Kuzṇecovs, V. Vājprātīgo nams Rīgas Citadelē (1787-1823). Latvijas

Universitātes Raksti. Zinātņu vēsture un muzejniecība, Nr.704, 2007, 62.-71. lpp.

Kuzņecovs, V., Vīksna, A. Eigēnika Latvijas Universitātē. Latvijas Universitātes Raksti. Zinātņu vēsture un muzejniecība, Nr.780, 2012, 166.174. lpp.

Lapin̦š, U. Ārzemju latviešu ārsts Miķelis Kazaks (1884-1968). Latvijas Medicīnas augstskola. Rīga : AML, 1995, 54.-56. 1pp.

Liepiṇšs, K. V. Akadēmiskās dzīves atbildīgais redaktors dr. Ansis Karps septiņdesmitpiecgadnieks. Akadēmiskā Dzīve, 1966, 80.-82. lpp.

Lipša, I. Sabiedriskā tikumība Latvijā 1918-1940. Promocijas darbs. Latvijas Universitāte; zin. vad. Aivars Stranga. Rīga, 2009. 290 lpp.

Lībiete, I. Fighting Sshizophrenia: Beginnings of Somatic Treatments in Psychiatry in Riga Sarkankalns Hospital in the 1930s. Baltic Journal of European Studies, vol.1, No.1(9), 2011, pp. 257-268.

Lībiete, I. Latvijas Universitātes Psihiatrijas katedras izveide un darbība 20. gs. 20. gados. Latvijas Universitātes Raksti. Zinātņu vēsture un muzejniecība, Nr.763, 2011, 54.-64. lpp.

Lībiete, I. Latvijā pirmā psihiatriskā kolonija ārsta Arnolda Laksberga atmin̄ās. Acta Medico-Historica Rigensia, Nr.9, 2010, 368.-376. lpp.

Lūse, A. From social pathologies to individual psyches: psychiatry navigating socio-political currents in $20^{\text {th }}$ century Latvia. History of Psychiatry, No.22, 2011, pp. 20-39.

Marti-Ibanez, F., Sackler, A. M., Sackler, M. D., Sackler, R. R. (eds.) The Great Physiodynamic Therapies in Psychiatry: An Historical Reappraisal. New York : Hoeber-Harper, 1956. 190 pp.

Meduna, L. J. The Convulsive Treatment: A Reappraisal // The Great Physiodynamic Therapies in Psychiatry: An Historical Reappraisal. Ed. by F. Marti-Ibanez, A. M. Sackler, M. D. Sackler \& R. R. Sackler, New York : Hoeber-Harper, 1956, pp. 76-90. 
Micale, M., Porter, R. Discovering the History of Psychiatry. New York : Oxford University Press, 1994. 466 pp.

Miltiņš, A., Vasariņ̌š, P. Klīniskā dermatovenerologija. Rīga : Zvaigzne ABC, 1999. 476 lpp.

Ozols, J. Goda tiesas darbība Latvijas Universitātē pirmajos divdesmit Latvijas pastāvēšanas gados. Latvijas Universitātes Raksti. Zinātņu vēsture un muzejniecība, Nr.639, 2001, 75.-100. lpp.

Pone, K. In memoriam. Dr. Ansi Karpu pieminot. Latvijas Ārstu un Zobārstu Apvienības Apkārtraksts, Nr.98, 1970, 22.-23. lpp.

Porter, R. Madness. A Brief History. New York : Oxford University Press, 2002. 241 pp.

Priebe, S. Community mental health care in Europe - an overview. Medical Archives, No.57, 2003, pp. 51-55.

Purviṇš, I., Purviṇa, S. Praktiskā farmakologija. 3.izd. Rīga : Zāḷu infocentrs, 2002. 794 lpp.

Rancāns, E., Tērauds, E., Taube, M. Psychiatry in Latvia: a Journey Through the Past Three Centuries. Nordic Journal of Psychiatrie, vol.66, No.6, 2012, pp. 428-432.

Sakel, M. The Classical Sakel Shock Treatment: A Reappraisal // The Great Physiodynamic Therapies in Psychiatry: An Historical Reappraisal. Ed. by F. Marti-Ibanez, A. M. Sackler, M. D. Sackler \& R. R. Sackler, New York : Hoeber-Harper, 1956, pp. 13-75.

Shorter, E. A Historical dictionary of Psychiatry. New York : Oxford University press, 2005. $338 \mathrm{pp}$.

Shorter, E. A History of Psychiatry: From the Era of the Asylum to the Age of Prozac. New York : John Wiley \& Sons, 1997. 436 pp.

Shorter, E. The 20s: an Overview // A Century of Psychiatry. Vol.1, Ed. by H. Freeman et.al., London : Mosby-Wolfe Medical Communications, 1999, pp. 63-68.

Sočṇeva, Z., Liepiṇšs, J. No Aleksandara Augstumu slimnīcas vēstures. Acta medico-historica Rigensia, vol.3, 1997, 99.-106. lpp.

Stradiṇš, J. Zinātnes un augstskolu sākotne Latvijāa. Rīga : Latvijas Vēstures institūta apgāds, 2009. 639 lpp.

Šuvajevs, I. Psihoanalīzes pēdas Latvijā. Rīga : LU akadēmiskais apgāds, 2012. 251 lpp.

Torrey, E. F., Yolken, R. H. Psychiatric genocide: Nazi Attempts to Eradicate Schizophrenia. Schizophrenia Bulletin, vol.36, No.1, 2010, pp. 2632. 
Tuters, K., Viksna, A. The Extermination of Psychiatric Patients in Latvia During World War II. International Journal of Mental Health, vol.35, No.3, 2006, pp. 72-74.

Vatere, E. Ebreji - mediķi Latvijā 1918-1996. Rīga : Latvijas Medicīnas akadēmija, 1997. 258 lpp.

Vīksna, A. Profesors Hermanis Buduls. Rīga : Medicīnas zinātniskā bibliotēka, 2002. 45 lpp.

Vīksna, A. Latviešu ārsti pasaulēe. Red. P. Apinis, Rīga: Rīgas starptautiskais medicīnas zinātnes un farmācijas centrs, 1993. 66 lpp.

Vīksna, A. Latvijas Universitātes Medicīnas fakultāte 1919-1950. Rīga : LU akadēmiskais apgāds, 2011. 412 lpp.

Vīksna, A. LU Medicīnas fakultātes absolventi (1920-1950): avoti un apkopojums. Latvijas Universitātes Raksti. Zinātņu vēsture un muzejniecība, Nr.738, 2008, 63.-77. lpp.

Vīksna, A. Neirologijas saknes Latvijā. Latvijas Ārsts, Nr.2, 2003, 10.-12. lpp.

Vīksna, A. Profesors Hermanis Buduls un viņa vieta Latvijas psichiatrijas vēsturē. Latvijas Ārstu Žurnāls, Nr.11/12, 2002, 55.-59. lpp.

Vīksna, A. Psihiatra jubileja. Veselība, Nr.12, 1976, 20. lpp.

Vīksna, A. Psihiatrijas saknes Latvijā. Latvijas Ārsts, Nr.10, 2003, 7.-9. lpp.

Vīksna, A. Veselības aizsardzības sākumi Padomju Latvijā 1917-1919. Rīga : Zinātne,1974. 90 lpp.

Vīksne, R. Garīgi slimo iznīcināšana Latvijā nacistiskās okupācijas laikā. Latvijas vēsturnieku komisijas raksti: holokausta izpētes jautājumi Latvijā, Nr.8, 2007, 324.-347. lpp.

Whitrow, M. Wagner - Jauregg and Fever Therapy. Medical History, vol.34, 1990, pp. 294-310.

Zalcmanis, R. u.c. Rīgas ielas. 1. sēj., Rīga : Apgāds Priedaines, 2001. 237 lpp.

Zelče, V. Vara, zinātne, veselība un cilvēki: eigēnika Latvijā 20. gs. 30. gados. Latvijas Arhīvi, Nr.3, 2006, 94.-137. lpp.

Zelčs, J. Ieslodzījuma vietu attīstība Latvijā pirmajos Valsts pastāvēšanas gados. Latvijas Arhīvi, Nr.1, 2011, 58-85.1pp.

Виксна, Ф ., Эглитис, И. Арнольд Фрицевич Лаксберг. Из истории медицины, т.14, 1984, с. 156-157.

Журавель, В. А. Владимир Федорович Чиж как психолог (1855-1922): малоизвестные страницы жизни и научного творчества (к 150-летию со 
дня рождения). Часть І. Обозрение психиатрии и медицинской психологии, т.1, 2005, с. 27-29.

Озолиньш, В. А. Организация психиатрической помощи в Прибалтике в XIX веке. Из истории медицины, т.6, 1964, с. 158-161.

Руссинов, А. Л. Первые исследования статистики самоубийств в лифляндской губернии в XIX веке. Из истории медицины, т.8, 1969, с. 206-208.

Руссинов, А. Л. К вопросу истории самоубийств. Из истории медицинны, т.9, 1973, с. 213-217.

Сочнева, 3. Г. Основные этапы развития психиатрической помощи в Латвии. Из истории медицины, т.11, 1979, с. 47-54.

Сочнева, 3. Г. Развитие психиатрической помощи в советской Латвии. Из истории медицины, т.6, 1964, с. 60-68.

Страдынь, П. И., Васильев К. Г. Доктор Отто Гун - выдающийся деятель отечественной медицины. Из истории медищины, т.2, 1959, с. 17 30.

Эглитис, И. Музей истории больницы. Из истории медицины, т. 19, 1990, c. $186-189$.

Эглитис, И. Музеи истории психиатрии при Елгавской психиатрической больнице и коллекция А. Ф. Лаксберга. Становление науки и научных коллективов Прибалтики, 1985, с. 343-344.

Эглитис, И. Херманис Будулис. Из истории медищины, т.19, 1990, с. 140-145.

Эглитис, И., Киршенталс, О. Х. Рижскому психоневрологическому диспансеру - сорок лет. Из истории медииины, т.18, 1989, с. 222-224. 